\title{
ВИКОРИСТАННЯ ТАКСОНОМІЇ В УДОСКОНАЛЕННІ КОНТЕНТУ ПІСЛЯДИПЛОМНОГО НАВЧАННЯ
}

\author{
О. П. Мінцер, М. А. Попова ${ }^{1}$, О. К. Ладичукํㅡ, С. П. Кошова \\ Національна медична академія післядипломної освіти імені П. Л. Шупика \\ ${ }^{1}$ Національний чентр «Мала академія наук України»
}

\begin{abstract}
Стаття присвячена вирішенню проблеми представлення медичних знань у процесі вдосконалення контенту післядипломного навчання для зменшення когнітивного навантаження. Розглянуто види когнітивного навантаження та шляхи його зменшення. Запропоновано використання таксономізації природномовних текстів в якості підходу до структуризації медичної інформації та онтології для інтегрованого подання агрегованих інфрормаційних ресурсів у процесі навчання. Наведено приклад використання онтології як ефрективного засобу зменшення когнітивного навантаження.
\end{abstract}

Ключові слова: когнітивне навантаження, таксономія, таксономізація природомовних текстів, онтологія, інтероперабельність.

\section{TAXONOMY USAGE FOR POSTGRADUATE CONTENT IMPROVEMENT}

\author{
O. P. Mintser, M. A. Popova ${ }^{1}$, O. K. Ladychuk ${ }^{1}$, S. P. Koshova \\ Shupyk National Medical Academy of Postgraduate Education \\ ${ }^{1}$ National center «Junior academy of science of Ukraine»
}

\begin{abstract}
Background. The article is devoted to solving the problem of presenting medical knowledge in the process of content improving for postgraduate education to reduce cognitive load. The purpose: to highlight the methods of taxonomization of natural language texts and the formation of medical knowledge ontologies to improve the content of postgraduate education in order to reduce cognitive load.

Materials and methods. Results. Types of cognitive load and ways to reduce it are considered. The use of natural language texts taxonomization as an approach to the structuring of medical information and ontology for the integrated presentation of aggregated information resources in the learning process is proposed. An example of using ontology as an effective means of reducing cognitive load is given.

Conclusions. When developing the content of postgraduate studies, it is necessary to take into account the balance of types of cognitive load and follow certain rules to eliminate congestion. The use of taxonomy techniques for postgraduate content reduces cognitive load due to clear organization of terms and integrated presentation of aggregated information resources.
\end{abstract}

Key words: cognitive load, taxonomy, natural language texts taxonomization, ontology, interoperability.

\section{ИСПОЛЬЗОВАНИЕ ТАКСОНОМИИ В СОВЕРШЕНСТВОВАНИИ КОНТЕНТА ПОСЛЕДИПЛОМНОГО ОБРАЗОВАНИЯ}

\author{
О. П. Минцер, М. А. Попова ${ }^{1}$, А. К. Ладычук ${ }^{1}$, С. П. Кошевая
}

Национальная медицинская академия последипломного образования имени П. Л. Шупика

${ }^{1}$ Национальный центр «Малая академия наук Украины»

\begin{abstract}
Статья посвящена решению проблемы представления медицинских знаний в процессе совершенствования контента последипломного обучения для уменьшения когнитивной нагрузки. Рассмотрены виды когнитивной нагрузки и пути её уменьшения. Предложено использование таксономизации естественно-языковых текстов в качестве подхода к структуризации медицинской информации и онтологии для интегрированного представления агрегированных инфрормационных ресурсов в процессе обучения. Приведен пример использования онтологии как эффективного средства уменьшения когнитивной нагрузки.
\end{abstract}

Ключевые слова: когнитивная нагрузка, таксономия, таксономизация естественно-языковых текстов, онтология, интероперабельность. 
Вступ. Відповідно до теорії когнітивного навантаження [1] робоча пам'ять має обмежену місткість, тому розробники навчального контенту повинні уникати перевантаження додатковими елементами, що не привносять нічого істотного в процес отримання знань. Адже чим більше інформації отримують суб'єкти навчання за один раз, тим менше ймовірність, що вони запам'ятають ії та зможуть застосувати в майбутньому.

При розробленні контенту післядипломного навчання важливо переконатися, що інформація $\epsilon$ зрозумілою та залишиться в пам'яті, перетворюючись на знання, які можна буде застосовувати в майбутньому. Тому розробник має бути обізнаним у технологіях навчання та мати уявлення, як працювати 3 інформацією для найбільш ефективного iii представлення для сприйняття та засвоєння: розуміти основи теорії когнітивного навантаження і застосовувати іiї при створенні навчального контенту з тим, щоб суб' єкти навчання отримали максимум користі.

Для вирішення проблем когнітивності та кореферентності медичної інформації нами запропоновано використання представлення первинної структури тексту у вигляді таксономії [2-8].

Мета роботи: висвітлення прийомів таксономізації природномовних текстів і формування онтологій медичних знань для вдосконалення контенту післядипломного навчання 3 метою зменшення когнітивного навантаження.

Результати та їх обговорення. Поняття та види когнітивного навантаження. Теорія когнітивного навантаження заснована на загальноприйнятій моделі оброблення інформації людиною, відповідно до якої цей процес залучає три види пам'яті: сенсорну, робочу (короткострокову) та довгострокову. Інформація з сенсорної пам'яті потрапляє в робочу пам'ять і вже там вона або обробляється, або остаточно відкидається. Після оброблення в робочій пам'яті, мозок розподіляє інформацію за категоріями та просуває в довгострокову пам'ять, де вона зберігається в деяких структурах або конструкціях, що відповідають за процес мислення і розв'язання завдань, - схемах. Схеми організовують інформацію в залежності від того, як вона буде використовуватися. Наприклад, поведінкові схеми дозволяють докладати менше зусиль для здійснення будь-якої дії завдяки частим повторенням, що називається автоматикою. Чим більше автоматик у людини, тим більшу кількість інформації вона може запам'ятати. Також схеми дозволяють сприймати різні елементи як єдине ціле, що формує нашу базу знань. Відповідно до теорії схем, між суб' єктом навчання та викладачем $€$ ключова відмінність: у суб'єкта навчання ще не сформувалася когнітивна схема, що наявна у викладача. Отже, створюючи нові схеми в процесі навчальної діяльності можна збільшувати обсяг робочої пам'яті.

Сучасні інформаційно-комунікаційні технології (IКT) покликані підвищити ефективність навчання завдяки новітнім форматам подання інформації (анімація, сторітеллінг, спливаючі підказки тощо). Однак часто через перевантаження різноманітними прийомами та дизайнерськими рішеннями інформаційні навчальні середовища досить захаращені. Тому для оптимізації навчального контенту необхідно розуміти який тип когнітивного навантаження вона викликатиме.

Враховуючи той факт, що робочою пам'яттю може бути оброблена обмежена кількість елементів, що взаємодіють одночасно, а довгостроковою - не обмежена, тому чим більше елементів студент утримує в довгостроковій пам'яті, тим легше йому буде виконати навчальне завдання, оскільки об'єм робочої пам'яті обмежений лише під час роботи з новою інформацією. Тобто, завдання матиме внутрішне когнітивне навантаження, що впливає на складність його виконання, експертизу, а також потужність робочої пам'яті студента.

Додаткове навантаження, що накладається неякісно розробленим навчальним контентом (неергономічні шрифти та одночасне використання кількох їхніх видів; нечитабельні написи, малюнки, графіки та їх надмірність; монотонне викладання або використання складної лексики тощо) та/або відволікаючими факторами (соціальні мережі, фонова музика, сторонні розмови в аудиторії тощо) та впливає на пізнавальну здатність людини, називається стороннім (зовнішнім) когнітивним навантаженням.

Германське (доиільне) когнітивне навантаження дозволяє зосередитись на процесі навчання та спрямоване на інтеграцію нової інформації з наявними знаннями для розвитку бази знань суб'єкту навчання.

При розробленні навчального контенту необхідно пам'ятати, що ці три типи когнітивного навантаження тісно пов'язані між собою: якщо приділяти багато уваги уникненню перших двох, то для третього не вистачить місця через когнітивне перевантаження. 
Отже, при розробленні контенту післядипломного навчання необхідно дотримуватися таких правил:

- усвідомлювати наскільки складним є сприйняття навчального контенту студентами для виконання завдання, щоб уникнути внутрішнього перевантаження;

- максимально оптимізувати подання інформації та зменшити відволікаючі фактори, щоб уникнути стороннього перевантаження;

- стимулювати германське навантаження.

Комп 'ютерна онтологія як тип представлення навчального контенту. Будь-який навчальний контент повинен містити та відображати понятійну систему теорії, що визначає предметну дисципліну. Структура такого контенту має відображати основні та допоміжні терміни, поняття, їхні властивості та взаємозв'язки. Кажучи формальною мовою, зміст контенту породжується непустою множиною взаємопов'язаних дефініцій понять, виражених іменами концептів навчальної дисципліни та їхніми описами, що ми називатимемо термінополем [8].

Поняття-концепти термінополя навчальної дисципліни формують певний глосарій, проте головним компонентом навчального контенту $є$ контексти, що визначають властивості та функціональність його понятійної системи. Фактично термінополе визначає понятійну основу взаємодії суб'єктів навчання 3 навчальним контентом, один iз одним і з викладачем. Множина взаємозв'язків між поняттями визначається множиною їх властивостей, описаних у контекстах цих понять, та представляються у вигляді певного впорядкування.

Найбільш ергономічним типом представлення навчального контенту, зокрема неструктурованих текстових масивів, є комп'ютерна онтологія [9] модель, що відображає всі поняття-концепти та семантичні зв' язки між ними, здатна підтримати процес післядипломного навчання за рахунок відображення контенту у вигляді таксономії — структури ієрархічного упорядкування, класифікації, узагальненої логічної ознакової моделі класів понять-концептів. Структурування контенту забезпечує ефект швидкого пошуку необхідної інформації у відносно повільній людській пам'яті. Процес послідовного прочитання тексту не дає можливості отримати повну інформацію стосовно поняття миттєво, одноразово (наприклад, якщо поняття зустрічається в різних розділах). Тому процес читання тексту повинен допускати можливість «дозування», аналізу окремих частин моделей класів концептів. Оскільки в різних процесах обробки інформації поняття представляються одним 3 двох способів: ім'ям (згорнуте, конверговане подання) або у вигляді набору значень ознак (розгорнуте подання), таксономія має забезпечувати зручний перехід від одного подання до іншого [10].

Застосування прийомів таксономізації контенту післядипломного навчання зменшує когнітивне навантаження завдяки чіткій організації термінів контрольованого словника в ієрархію, щоб відфільтрувати зайву та сміттєву інформацію, що може відвернути увагу. При цьому основною метою таксономії є створення базису онтології для забезпечення спільного розуміння термінів між студентами та викладачами/фахівцями/експертами та інтеграції й агрегації інформаційних ресурсів i навчально-освітніх систем таким чином, щоб уникнути необхідності шукати потрібний контент по фізично та тематично розподілених базах даних, електронних бібліотеках, архівах тощо, а вся необхідна для засвоєння інформація була б доступна в єдиному середовищі.

Формальне представлення таксономізацї природномовних текстів. Уведемо певну формалізацію понять. Як зазначалося вище, структура природномовного тексту $T_{n l}$ складається із множини концептів $c_{1}, c_{2}, c_{3}, \ldots, c_{n} \mid c_{i} \in C$ (термінів, окремих слів або символьних (логікових) формул) та відношень $r_{1}, r_{2}, r_{3}, \ldots, r_{n} \mid r_{i} \in R$ між ними. Оскільки текст є лінійно впорядкованою множиною речень $\mathrm{S}$, об'єднаних відношенням передування $\prec$, то формально його можна представити у вигляді:

$$
T_{n l}=\left\{S_{1} \prec S_{2} \prec \cdots \prec S_{n_{s}}\right\},
$$

де $S_{i} \in C_{S_{i}}=\left\{c_{i j}, j=\overline{1 \ldots n_{l}}\right\}$ - множина концептів, що входять до речення, $n_{i}$ - кількість концептів у кожному реченні, $n_{s}$ - загальна кількість речень у тексті.

Кожний концепт, описаний текстом $c_{i j}^{T}$, має властивості $P_{i j}$ та синтаксичні зв'язки з іншими концептами $r_{i j}=<c_{i j}^{1}, c_{i j}^{2}, k>$, де $\mathrm{k}-$ тип відношень:

$$
c_{i j}=<c_{i j}^{T}, P_{i j}, r_{i j}>\text {. }
$$

Таку структуру тексту можна представити у вигляді дводольного орієнтованого графу, вершини якого представлені іменами концептів, а ребра відношеннями між ними:

$$
T_{n l}=<C, R>\text {. }
$$


Оскільки проблема когнітивного перевантаження спричинена низькою ефективністю роботи 3 текстовим представленням концепту $c_{i j}^{T}$, що часто $€$ надлишковим і вимагає надбудови спеціалізованих функцій, визначених на множині текстових представлень слів, а множина текстових представлень концептів є зліченною, то можемо побудувати перетворення виду:

$V: C^{T} \rightarrow \mathbb{N}$, де $C^{T}$ - множина текстових представлень концептів.

Будь-який текст виражений певним алфавітом $W$, кількість символів в якому $n_{W}=\operatorname{card}(W)$ розглядається як система числення з основою $n_{W}$ , а кожній літері $w \in W$ можна поставити у відповідність певне число $i_{w} \in \mathbb{N}$, що являє собою індекс даної літери в алфавіті. Тоді будь-яке слово тексту $є$ послідовністю:

$$
c^{T}=\left\{w_{1}, w_{2}, \ldots, w_{n_{c}}\right\}
$$

де $n_{c}$ - довжина слова $n_{c}>0 ; w_{i}$ - літери алфавіту $W$.

Якщо розглядати літери $w_{i}$ як розряди числа у відповідній системі числення, то таке число можна перевести в десяткову систему числення за допомогою формули:

$$
\begin{aligned}
& V\left(c^{T}\right)=i_{w_{1}} \times\left(n_{W}\right)^{n_{c}}+i_{w_{2}} \times \\
& \times\left(n_{W}\right)^{n_{c}-1}+\cdots+i_{w_{n c}} \times\left(n_{W}\right)^{0},
\end{aligned}
$$

де $i_{w_{j}}$ - індекс літери $w_{j}$ в алфавіті $W ; n_{W}-$ кількість символів в алфавіті $W$.

За допомогою функції $V$ можна замінити всі $c^{T}$ на відповідні їм $c^{V}=V\left(c^{T}\right)$ таким чином, щоб отримати більш ефективне представлення множини концептів:

$$
<c^{V}, P>\in C^{V},
$$

де $c^{V}$ - кодове представлення концепту с; $P$ - граматичні характеристики концепту; $c^{V}-$ множина кодових представлень концептів.

$\mathrm{y}$ подальшому $c^{V}$ можна розглядати в якості множини концептів C [11].

Отже, таксономія є представленням певного обсягу тематичних знань у вигляді природномовних конструкцій [12], що відображають висловлення, судження та твердження про певні факти предметно-тематичного профілю, які пов'язані між собою множинами відношень і характеризуються певними властивостями. Здебільшого навчальний контент являє собою природномовні описи в науковому стилі та призначений для передачі певних відомостей або пояснення певних фактів 3 наукової точки зору, а тому характеризується вживанням спеціалізованих термінів та професійної лексики. Тому, таксономія може стати якісним «маршрутизатором» тематичним контентом, забезпечуючи їі використання при подальшому отриманні інформації з інших джерел, систем і ресурсів.

Використання онтології для усунення лексичної багатозначності медичної інформачії у прочесі ї̈ інтеграиії та агрегаиії. Методичним завданням iз застосування таксономії є компетентна інтерпретація понятійної системи, аксіоматики, правил, синтаксичних та морфологічних основ дисципліни, що вона представляє, для забезпечення формування операціонального простору діяльності суб'єктів навчання, в якому вони мають змогу взаємодіяти 3 навчальним контентом.

При цьому зазначимо, що таксономізація природномовних текстів, перш за все, орієнтована на дослідження реальності, що описана в них. Зрозуміло, що під «поза текстовою» реальністю маються на увазі не тільки ті реальні події, факти, відносини, про які йде мова в тексті, скільки ті установки та інтереси, які визначають принципи відбору матеріалу для навчального процесу та які присутні в тексті неявним чином. Це означає, що для суб'єкту навчання може бути рівною мірою важливим як те, що описано в тексті, так і те, що виявилося поза його рамками.

Оскільки інформаційні процеси, що характеризують сучасне суспільство та визначають економіку знань, висувають до функціональних властивостей таксономії вимоги інтерактивності та інтероперабельності інформації, що складає навчальний контент, виникає необхідність застосування сучасних засобів IT-технологій, спроможних забезпечити інтерактивність його змісту та інтероперабельне інтегроване використання інформаційних середовищ, ресурсів і мережевих інформаційних систем. Поняття інтегрованості змісту таксономії визначає наявність інструментів пошуку, категоризації, класифікації та визначення його тематичної еквівалентності за змістом із зовнішніми мережевими інформаційними ресурсами [13].

Рішенням $\epsilon$ використання онтологій, що охоплюють більш широку сферу, ніж деталізований набір понять та відношень. Хоча онтологія, як і iii основа - таскономія, є відображенням певної 
дисципліни, вона може бути представлена у вигляді активної системи знань, що містить не лише множину пов' язаних об'єктів із описами, а й формальні аксіоми, які обмежують інтерпретацію та спільне вживання термінів. Онтологію можна розглядати як певну експліцитну концептуалізацію логічної теорії, деякого числення з певними правилами [14]. Семантичні правила, що визначаються системою онтологій, забезпечують формування класів понять кількох таксономій, зв'язування їх між собою відповідними множинними відношеннями та визначення функціоналу, що створює операціональне середовище онтологічної системи контекстних описів навчального контенту.

В процесі упорядкування знань часто виникають проблеми наявності різних слів однакового написання із різними значеннями (омонімія) та лексичних значень у одного й того ж слова відповідно до різних контекстів (полісемія). Крім того, має місце явище кореферентності медичної інформації. На сьогоднішній день існує багато досліджень, що пропонує використання онтологій для усунення лексичної багатозначності [15-17]. Онтології не вимагають наявності ані великого корпусу текстів, на відміну від імовірнісних методів, ані великого числа правил, як формальні методи, що значно розширює сферу їх використання. Проблему кореферентності пропонується вирішувати шляхом використання семантичних анотацій, що додаються до ідентифікованих згадувань у середовищі онтології $[18,19]$. На практиці, ефективність застосування онтології у процесі інтеграції та агрегації інформаційних ресурсів істотно залежить від якості таксономізації предметної області. Тому питання, пов' язані з упорядкуванням знань в множини концептів таксономії, визначають конструктивність онтології як системи знань.

Спосіб представлення медичних знань для зменшення когнітивного навантаження на прикладі онтології «Іиемічна хвороба серияя. Важливою властивістю таксономії $є$ здатність представлення структурованої інформації одночасно iз iii сприйняттям. У цьому випадку формування структури пам'яті відбувається за рахунок взаємодії інформації, що сприймається, i інформації, яка вже зберігається у мережевому графі. В результаті здійснення процесів структурування інформації встановлюється семантична та синтаксична близькість інформації. Знайдені асоціативні зв'язки закріплюються у структурних компонентах пам'яті.

Структуризація медичних знань шляхом так-

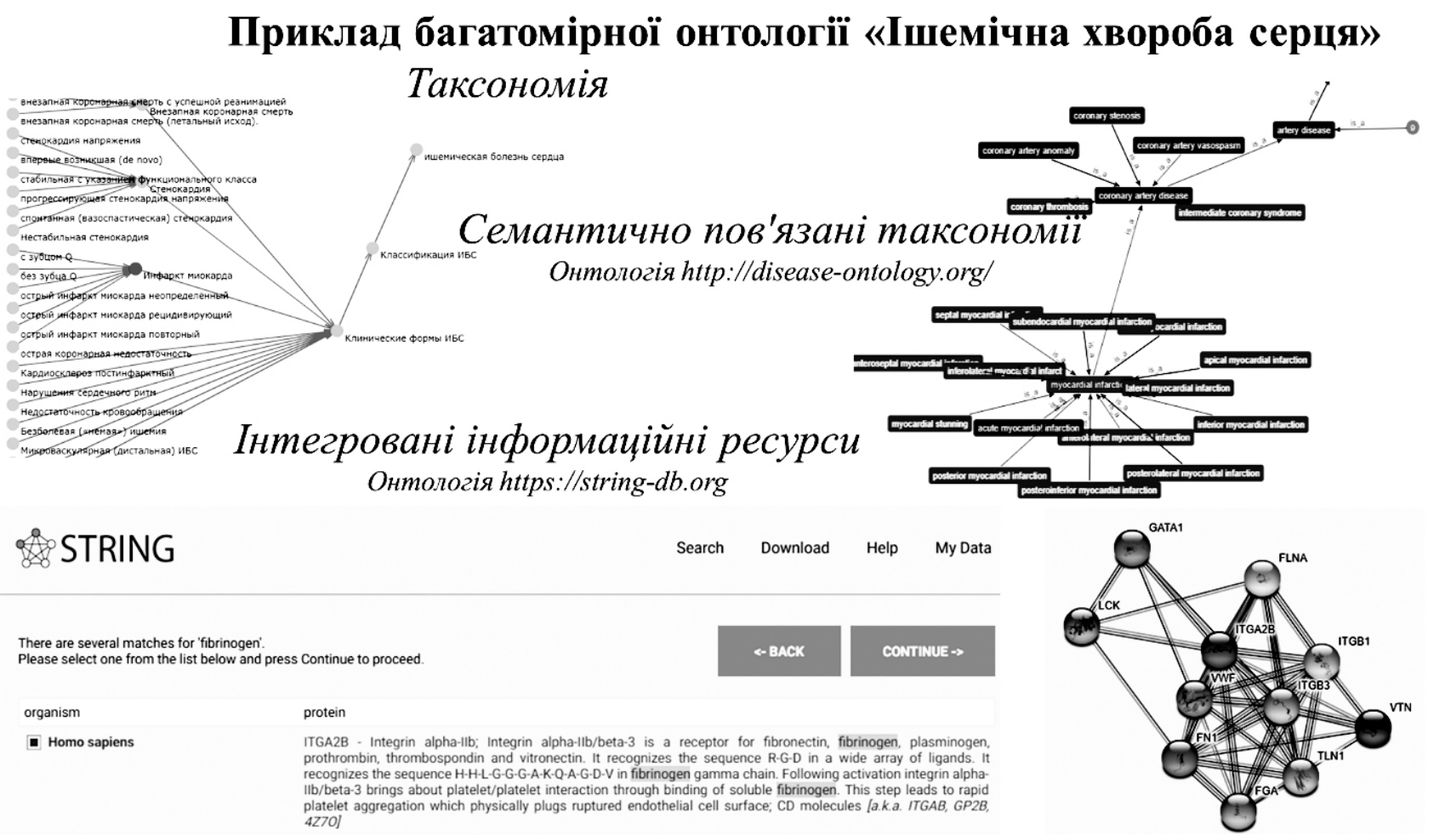

Рис. 1. Онтологія «Ішемічна хвороба серця» 
сономізації медичних текстів, що описують ці знання, для відображення семантики інтегрованих та агрегованих інформаційних ресурсів у вигляді ієрархічних структур, над якими задається певна розширювана аксіоматика $\mathrm{i}$ між якими визначаються множини відношень, дозволяє вирішити проблему їх коректної інтерпретації в процесі використання онтології.

Онтологія «Ішемічна хвороба серця» (рис. 1) за глибиною концептуалізації області знань є онтологією домену (предметної області), що порівняно $з$ більш формальними онтологіями верхнього рівня $\epsilon$ низькорівневою. Під глибиною бінарних відношень таксономії даної онтології розуміємо глибину вкладеності категорій концептів, що в термінах графа означає, що є певна відстань між термінальною і кореневою вершинами, що перевищує один крок. По-друге, нами розглядається поняття «зовнішнього» рівня онтології, що характеризується кількістю ітерацій пошуку запиту користувача 3 контексту концепту таксономії в інтегрованих до онтології джерелах інформації.

\section{Література.}

1. Sweller J. Cognitive Load Theory, learning difficulty, and instructional design / J. Sweller // Learning and Instruction. — 1994. — Vol. 4, № 4. — P. 295-312.

2. Мінцер О. П. Онтолого-керовані інформаційні системи в забезпеченні безперервного професійного розвитку лікарів та провізорів / О. П. Мінцер, М. А. Попова // Медична освіта. - 2019. - Вип. 2. - С. 171-177.

3. Персоніфікована медицина як глобальна об'єднуюча мета розвитку страхової та системної медицини / О. П. Мінцер, Є. В. Горшков, О. І. Твердохліб, М. А. Попова, П. П. Ганинець, О. В. Сарканич // Медична інформатика та інженерія. — 2019. — № 2. - С. 38-44.

4. Використання медичних онтологій в навчальному процесі / М. А. Попова, О. К. Ладичук, В. В. Приходнюк // Наукові записки Малої академії наук України. Серія «Педагогічні науки». - Київ : Національний центр «Мала академія наук України». - 2019. Вип. 14. - С. 11-17.

5. Мінцер О. П. Системна біомедицина. Монографія. Т. 1. / О. П. Мінцер, В. М. Заліський. — К.: Інтерсервіс, 2019. - 552 c.

6. Ладичук О. К. Онтології як інноваційний STEMінструмент інтерактивного навчання в медичній освіті / О. К. Ладичук, М. А. Попова // Актуальні аспекти розвитку STEM-освіти у навчанні природ-
Саме таке представлення предметних знань значно зменшує когнітивне навантаження.

Висновки. 1. При розробленні контенту післядипломного навчання необхідно враховувати збалансованість видів когнітивного навантаження та дотримуватися певних правил задля усунення перевантаження.

2. Застосування прийомів таксономізації контенту післядипломного навчання зменшує когнітивне навантаження завдяки чіткій організації термінів та інтегрованому представленню агрегованих інформаційних ресурсів.

3. Структуризація медичних знань шляхом таксономізації природномовних текстів дозволяє вирішити проблему їх коректної інтерпретації у процесі використання онтології для післядипломного навчання.

4. Комп'ютерна онтологія забезпечує інтерактивність та інтероперабельність медичної інформації, усунення ії лексичної багатозначності в процесі інтегрованого застосування агрегованих інформаційних ресурсів для зменшення когнітивного навантаження.

ничо-наукових дисциплін : збірник матеріалів III Міжнародної науково-практичної конференції. Кропивницький : Льотна академія НАУ, 2020. - С. 129-131.

7. Попова М. А. Багаторівнева онтологія «Системна біомедицина» як інноваційний інструмент менеджменту знань / М. А. Попова, О. К. Ладичук // «Інноваційні трансформації в сучасній освіті: виклики, реалії, стратегії»: збірник матеріалів III Всеукраїнського відкритого науково-практичного онлайн-форуму. — Київ, 2020.

8. Стрижак О. Є. Таксономічні засади наративного дискурсу / О. Є. Стрижак // Медична інформатика та інженерія. — 2020. — № 2. — С. 137-147.

9. Sowa J. F. Knowledge Representation: Logical, Philosophical, and Computational Foundations / J. F. Sowa. - Pacific Grove, CA: Brooks Cole Publishing Co., 2000. - 594 p.

10. Попова М. А. Інструменти підтримки діяльності експерта при концепт-аналізі природно-мовних текстів (на прикладі порівняння законодавчих актів в сфері охорони та раціонального використання водних ресурсів України і Туркменістану) / М. А. Попова, Є. С. Анпілова // Радіоелектронні і комп’ютерні системи : науково-технічний журнал. — 2015. — № 3 (73). - С. 27-32.

11. Приходнюк В. В. Технологічні засоби трансдисциплінарного представлення геопросторової інформа- 
ції [Текст]: автореф. дис. ... к-та техн. наук : 05.13.06 / Приходнюк Віталій Валерійович ; Нац. акад. наук України, Ін-т телекомунікацій і глобал. інформ. простору. - К., 2017. - 20 с.

12. Приходнюк В. В. Таксономизация естественноязыковых текстов / В. В. Приходнюк // International Journal «Information Models and Analyses», 2016. Vol. 5, № 3. - C. 270-284.

13. Dovgyi S. Transdisciplinary Fundamentals of Information-Analytical Activity. / Dovgyi S., Stryzhak O. // Advances in Information and Communication Technology and Systems. MCT 2019. Lecture Notes in Networks and Systems. Springer, Cham. — 2020. — Vol. 152.

14. Guarino N. Understanding, Building, and Using Ontologies. — Режим доступу: http://ksi.cpsc.ucalgary. ca/KAW/KAW96/guarino/guarino.html.

15. Лесько О. Н. Использование онтологии предметной области для снятия омонимии в естественноязыкових текстах /О.Н.Лесько, Ю. В. Рогушина // Проблеми програмування. — 2017. — № 2. - С. 61-71.

16. Антонов Е. С. Разрешение онтологической и языковой омонимии именованных сущностей с помощью интерпретации данных онтологии / С. Е. Антонов // Вестник ТГПУ. - 2013. — №8 (136).

17. Utt J. Ontology-based distinction between polysemy and homonymy /J. Utt, S. Pado // Proceedings of the Ninth International Conference on Computational Semantics. - 2011. - P. 265-274.

18. Ontology-Based Coreference Resolution / R. Prokofyev, A. Tonon, M. Luggen, L. Vouilloz, D. E. Difallah, P. Cudré-Mauroux // The Semantic Web — ISWC 2015. ISWC 2015. Lecture Notes in Computer Science. Springer, Cham. - 2015. — Vol. 9366.

19. Taheri A. Instance Coreference Resolution in Multiontology Linked Data Resources/A. Taheri, M. Shamsfard // Semantic Technology. JIST 2012. Lecture Notes in Computer Science. Springer, Berlin, Heidelberg. — 2013. — Vol. 7774.

\section{References.}

1. Sweller J. (1994). Cognitive Load Theory, learning difficulty, and instructional design. Learning and Instruction, 4 (4), 295-312. doi: 10.1016/09594752(94)90003-5.

2. Mintser O. P., Popova M. A. (2019). Ontolohokerovani informatsiini systemy $\mathrm{v}$ zabezpechenni bezperervnoho profesiinoho rozvytku likariv ta provizoriv [Ontologically controlled information systems in ensuring the continuous professional development of doctors and pharmacists]. Medychna osvita \{Medical education\}, 2, 171-177 [In Ukrainian].

3. Mintser O., Horchkov Ye. V., Tverdohlib O. I., Popova M. A., Hanynets P. P., Sarkanych O. V. (2019). Personifikovana medytsyna yak hlobalna obiednuiucha meta rozvytku strakhovoi ta systemnoi medytsyny [Personalized medicine as a global unifying goal for the development of insurance and systems medicine]. Medychna informatyka ta inzheneriia \{Medical informatics and engineering\}, 2, 38-44 [In Ukrainian]. 4. Popova M. A., Ladychuk O. K., Prykhodniuk B. B. (2019). Vykorystannia medychnykh ontolohii v navchalnomu protsesi [The use of medical ontologies in the educational process]. Naukovi zapysky Maloi akademii nauk Ukrainy. Seriia «Pedahohichni nauky» \{Scientific notes of Jonior Academy of Sciences of Ukraine. Pedagogical Sciences Series\}. Kyiv : National center «Junior academy of science of Ukraine», 14, 1117. [In Ukrainian].

5. Mintser O. P., Zalis`kyi V. M. (2019). Systemna biomedytsyna [Systemic biomedicine]. Kyiv, Interservis. [In Ukrainian].

6. Ladychuk O. K., Popova M. A. (2020). Ontolohii yak innovatsiinyi STEM-instrument interaktyvnoho navchannia v medychnii osviti [Ontologies as an innovative STEM-tool of interactive learning in medical education]. Proceedings from Aktualni aspekty rozvytku STEM-osvity u navchanni pryrodnycho-naukovykh dystsyplin - Current aspects of the development of STEM-education in the teaching of natural sciences. (129-131). Kropyvnytskyi : Flight Academy NAU. [In Ukrainian].

7. Popova M. A., Ladychuk O. K. (2020). Bahatorivneva ontolohiia «Systemna biomedytsyna» yak innovatsiinyi instrument menedzhmentu znan [Multilevel ontology «Systemic biomedicine» as an innovative tool of knowledge management]. Proceedings from Innovatsiini transformatsii v suchasnii osviti: vyklyky, realii, stratehii - Innovative transformations in modern education: challenges, realities, strategies. [In Ukrainian].

8. Stryzhak O. Ye. (2020). Taksonomichni zasady naratyvnoho dyskursu [Taxonomic principles of narrative discourse]. Medychna informatyka ta inzheneriia [Medical informatics and engineering], 2, 137-147. [In Ukrainian]. doi: https://doi.org/10.11603/ mie.1996-1960.2020.2.11186.

9. Sowa J. F. (2000). Knowledge Representation: Logical, Philosophical, and Computational Foundations. Pacific Grove, CA: Brooks Cole Publishing Co.

10. Popova M. A., Anpilova Ye. S. (2015). Instrumenty pidtrymky diialnosti eksperta pry kontseptanalizi pryrodno-movnykh tekstiv (na prykladi porivniannia zakonodavchykh aktiv v sferi okhorony ta ratsionalnoho vykorystannia vodnykh resursiv Ukrainy i Turkmenistanu) [Tools to support the activities of the expert in the conceptual analysis of natural language texts (on the example of comparing legislation in the field of protection and rational use of water resources of Ukraine and Turkmenistan)]. Radioelektronni $i$ kompiuterni systemy-Electronic and computer systems, 3 (73), 27-32. [In Ukrainian]. 
11. Prykhodniuk V. V. (2017). Tekhnolohichni zasoby transdystsyplinarnoho predstavlennia heoprostorovoi informatsii [Technological tools of transdisciplinary presentation of geospatial information]. Extended abstract of candidate's thesis. Kyiv: ITGIP NANU. [In Ukrainian].

12. Prykhodniuk V. V. (2016). Taksonomizacija estestvennojazykovyh tekstov [Taxonomization of natural language texts]. International Journal «Information Models and Analyses», 5 (3), 270-284. [In Russian].

13. Dovgyi S., Stryzhak O. (2020). Transdisciplinary Fundamentals of Information-Analytical Activity. In: Ilchenko M., Uryvsky L., Globa L. (eds) Advances in Infor-mation and Communication Technology and Systems. MCT 2019. Lecture Notes in Networks and Systems, Vol. 152. Springer, Cham. doi: https://doi. org/10.1007/978-3-030-58359-0_7.

14. Guarino N. Understanding, Building, and Using Ontologies. Retrieved from http://ksi.cpsc.ucalgary.ca/ KAW/KAW96/guarino/guarino.html.

15. Les`ko O. N., Rogushyna Yu. V. (2017). Ispol’zovanie ontologii predmetnoj oblasti dlja snjatija omonimii v estestvenno-jazykovih tekstah [Using the ontology of the subject area to remove homonymy in natural language texts] Problemy prohramuvannia - Programming problems, 2, 61-71. [In Russian].
16. Antonov Ye. S. (2013). Razreshenie ontologicheskoj i jazykovoj omonimii imenovannyh sushhnostej s pomoshh'ju interpretacii dannyh ontologii [Resolving the ontological and linguistic homonymy of named entities by interpreting ontology data]. Вестник ТГПУ - Bulletin of TGPU, 8, 136. [In Russian].

17. Utt J., Padó S. (2011). Ontology-based distinction between polysemy and homonymy. Conference: Proceedings of the Ninth International Conference on Computational Semantics, 265-274.

18. Prokofyev R., Tonon A., Luggen M., Vouilloz L., Difallah D.E., Cudré-Mauroux P. (2015). SANAPHOR: Ontology-Based Coreference Resolution. In: Arenas M. et al. (eds) The Semantic Web - ISWC 2015. ISWC 2015. Lecture Notes in Computer Science, Vol 9366. Springer, Cham. doi: https://doi.org/10.1007/978-3-319-250076_27.

19. Taheri A., Shamsfard M. (2013). Instance Coreference Resolution in Multi-ontology Linked Data Resources. In: Takeda H., Qu Y., Mizoguchi R., Kitamura Y. (eds) Semantic Technology. JIST 2012. Lecture Notes in Computer Science, vol 7774. Springer, Berlin, Heidelberg. doi: https://doi.org/10.1007/978-3-64237996-3_9. 